\title{
Lipid Metabolism Indices and Fatty Acids Profile in the Blood Serum of Broiler Chickens Fed a Diet with Lignocellulose
}

-Author(s)

\author{
Bogusławska-Tryk $\mathrm{M}^{\prime}$ \\ Piotrowska A' \\ Szymeczko R' \\ Burlikowska K \\ Głowińska B'
}

Department of Animal Physiology and Morphology, Faculty of Animal Breeding and Biology, UTP University of Science and Technology, Mazowiecka 28, 85-084 Bydgoszcz, Poland

\section{-Mail Address}

Corresponding author e-mail address Monika Bogusławska-Tryk

Department of Animal Physiology and Morphology, Faculty of Animal Breeding and Biology, UTP University of Science and Technology, Mazowiecka 28, 85-084 Bydgoszcz, Poland

Tel: (48) 523749754

Email: monika.boguslawska-tryk@utp. edu.pl

\section{EKeywords}

Blood parameters, broiler, fatty acids, fiber.

\section{ABSTRACT}

The aim of the research was to determine lipid metabolism indices and fatty acid profile in the blood serum of Ross 308 chickens $(n=48)$, fed a finisher mixture supplemented with $0,0.25,0.5$ and $1.0 \%$ of lignocellulose. The feeding trial lasted from 21 to $42 \mathrm{~d}$ of the birds' age. Blood samples were collected from each chicken at $42 \mathrm{~d}$ of age from the pterygoid canal vein. In the blood serum the content of triglycerides (TG), total cholesterol (TCHOL) and high density lipoprotein (HDL) fraction was determined by the spectrophotometric method. The fatty acids concentration was estimated with the use of the gas chromatography method. Lignocellulose in doses of 0.5 and $1.0 \%$ significantly reduced the concentration of triglycerides and low density lipoprotein (LDL) fraction. Saturated fatty acids (SFA) and monounsaturated fatty acids (MUFA) content was not affected by dietary treatments whereas lignocellulose significantly influenced the profile of polyunsaturated fatty acids (PUFA) from $n-3$ and $n-6$ families. Insoluble fiber decreased $(p<0.05)$ serum concentration of $\alpha$-linolenic acid (C18:3n-3) and increased share of docosahexaenoic acid (C22:6n-3), dihomogammalinolenic acid (C20:3n-6) and arachidonic acid (C20:4n-6) in total PUFA, compared to the control birds. The results of the present study have shown that the incorporation of limited amounts of lignocellulose into the broiler diet can influence the lipid metabolism in the chickens.

\section{INTRODUCTION}

It is widely accepted that dietary fiber affects gastrointestinal tract development, gut morphology and enzyme secretion, nutrient digestibility and absorption in poultry, and these effects depend on its physicochemical properties, dietary content, and bird age (Montagne et al., 2003; Sarikhan et al., 2010; Mateos et al., 2012). The trophic effect of fiber results from its impact on the bird's gut ecosystem, intensity of fermentation, and profile of short-chain fatty acids in the intestinal lumen (Montagne et al., 2003).

Traditionally, insoluble dietary fiber, consisting mainly cellulose and lignin, is considered as an energy diluent in poultry diets; however, it is documented that moderate quantities are indispensable for ensuring proper development and function of the digestive tract of poultry (Klapáčová et al., 2011; Mateos et al., 2012). It was shown that minor amounts of cellulose from different sources positively affect nutrient retention, decrease serum cholesterol levels, and alter the lipid profile in the liver and adipose tissue of broilers (Akiba \& Matsumoto, 1978, 1982; Sarikhan et al., 2009; Jiménez-Moreno et al., 2010; Safaa et al., 2014). On the other hand, purified lignin inhibits animal pancreatic enzymes activities in vitro and has a strong ability to bind cholesterol and bile acids from a micellar solution (Jung \& Fahey, 1983), which may affect lipid absorption and metabolism. 
Bogusławska-Tryk M, Piotrowska A, Szymeczko R, Burlikowska K, Głowińska B
Lipid Metabolism Indices and Fatty Acids Profile in the Blood Serum of Broiler Chickens Fed a Diet with Lignocellulose
Lignocellulose is the most available raw material in the world, and it is mainly used for the production of biofuels. It is composed of carbohydrates (cellulose, hemicellulose) and aromatic polymers (lignin), and lignocellulose composition and physical properties depend on its source (Harmsen et al., 2010).

To our knowledge, there are no comprehensive studies evaluating the effect of lignocellulose, which combines the properties of cellulose and lignin, on nutrient metabolism, health status and productivity of broilers. Preliminary research performed by Farran et al. (2013) demonstrated that lignocellulose at a dose of $0.8 \%$ increased protein digestibility and carcass yield, and significantly lowered abdominal fat pad in broiler chickens. Moreover, our preliminary studies also showed that, despite the lack of influence on broiler performance parameters, lignocellulose at a dose of $0.5-1.0 \%$ had beneficial effects on the intestinal microbiota and its fermentation activity (BogusławskaTryk et al., 2015).

There is a growing interest in evaluating the impact of dietary insoluble fiber inclusion on lipid metabolism in poultry (Sarikhan et al., 2009; Jiménez-Moreno et al., 2010; Safaa et al., 2014). However, there is lack of information regarding the effect of lignocellulose on broiler serum lipid profile. Therefore, the aim of this study was to determine the effect of increasing levels of lignocellulose in chicken diets on lipid metabolism indices and fatty acid profile in the blood serum of broilers.

\section{MATERIAL AND METHODS}

\section{Birds, housing and feeding}

All animal care procedures were approved by the Local Ethical Committee on Animal Testing at the UTP University of Science and Technology in Bydgoszcz.

A total of 48 21-d-old male Ross 308 chickens were obtained from a commercial farm. During the rearing period on the farm, up to $21 \mathrm{~d}$ of age, the chickens were fed a commercial starter (from 0 to $10 \mathrm{~d}$ of age) and grower diet (from 11 to $20 \mathrm{~d}$ of age). Upon arrival at the laboratory facilities, with automaticallycontrolled environmental conditions (temperature, humidity and air exchange), chickens were weighed and allocated to one of four treatment groups with a similar body weight distribution. Each group consisted of 12 birds kept in metabolic cages $(n=12)$. During the 21-day feeding trial (from 21 to $42 \mathrm{~d}$ of bird age), pelleted diets and water were supplied ad libitum. The chickens were reared according to the technological recommendations of the genetic company. The temperature in the laboratory was kept at $22{ }^{\circ} \mathrm{C}$ over a 3 -week experimental period. Continuous light was provided for $24 \mathrm{~h}$ per day.

The antibiotic and coccidiostat-free standard finisher diet was formulated to meet the minimum nutritional requirements of Ross 308 broilers (Nutrition Specification for Ross 308, 2007). The ingredients, analyzed chemical composition, fiber fractions, and fatty acid profile of the basal diet are shown in Table 1 and 2.The experimental diets varied in the amount of lignocellulose (Arboce ${ }^{\circledR} R C$, J. Rettenmaier \& Söhne $\mathrm{GmbH}+\mathrm{CO}$ ) incorporated into the basal diet at the expense of wheat: 0.0 (non-supplemented group), $0.25,0.5$ and $1.0 \%$. According to the manufacturer's data, the lignocellulose preparation contains about 91.5\% neutral detergent fiber (NDF), 70\% acid detergent fiber (ADF), and 24\% acid detergent lignin $(A D L)$, the length of fiber fraction is $200-300 \mu m$, and water absorption is about $500-700 \%$. The analyzed content of the fiber fractions in the experimental diets

Table 1 - Ingredient formulation and analyzed chemical composition of the basal $\operatorname{diet}^{*}$ ( $\mathrm{g} / \mathrm{kg}$, as-fed basis)

\begin{tabular}{|c|c|}
\hline \multicolumn{2}{|l|}{ Ingredients } \\
\hline Corn & 241.4 \\
\hline Wheat & 231.3 \\
\hline Triticale & 236.0 \\
\hline Soybean meal $46 \%$ & 238.0 \\
\hline Soybean oil & 20.0 \\
\hline L-Lysine & 1.0 \\
\hline DL-Methionine & 1.0 \\
\hline $\mathrm{Ca}\left(\mathrm{H}_{2} \mathrm{PO}_{4}\right)_{2}$ & 10.0 \\
\hline $\mathrm{CaCO}_{3}$ & 15.0 \\
\hline $\mathrm{NaCl}$ & 2.0 \\
\hline $\mathrm{Na}_{2} \mathrm{CO}_{3}$ & 2.0 \\
\hline Vitamin and mineral premix ${ }^{* *}$ & 2.2 \\
\hline Ronozyme P5000*** & 0.1 \\
\hline \multicolumn{2}{|l|}{ Analyzed chemical composition } \\
\hline Metabolisable energy(MJ/kg) & 12.8 \\
\hline Crude protein $(\mathrm{N} \times 6.25)$ & 195.7 \\
\hline Ether extract & 41.4 \\
\hline $\mathrm{N}$-free extractives ${ }^{* * * *}$ & 587.1 \\
\hline Crude fiber & 28.7 \\
\hline \multicolumn{2}{|l|}{ Fiber fractions: } \\
\hline Neutral detergent fiber & 81.5 \\
\hline Acid detergent fiber & 26.9 \\
\hline Acid detergent lignin & 4.9 \\
\hline \multicolumn{2}{|l|}{ "Basal diet: $0.0 \%$ of lignocellulose } \\
\hline \multicolumn{2}{|c|}{$\begin{array}{l}{ }^{* *} \text { Provided the following (per } \mathrm{kg} \text { of diet): vitamin } \mathrm{A}, 12500 \mathrm{IU} \text {; vitamin } \mathrm{D}_{3^{\prime}}, 1250 \mathrm{IU} \text {; } \\
\text { vitamin } \mathrm{E}, 37.5 \mathrm{mg} \text {; vitamin } \mathrm{K}, 1.25 \mathrm{mg} \text {; thiamin, } 1.88 \mathrm{mg} \text {; riboflavin, } 3.75 \mathrm{mg} \text {; pyrido- } \\
\text { xine, } 2.5 \mathrm{mg} \text {; cyanocobalamine, } 0.03 \mathrm{mg} \text {; biotin, } 0.06 \mathrm{mg} \text {; folic acid, } 0.38 \mathrm{mg} \text {; nicotinic } \\
\text { acid, } 18.75 \mathrm{mg} \text {; pantothenic acid, } 0.75 \mathrm{mg} ; \mathrm{Zn}, 120 \mathrm{mg} \text {; Fe, } 120 \mathrm{mg} \text {; Cu, } 20 \mathrm{mg} \text {; Co, } \\
0.8 \mathrm{mg} \text {; Se, } 0.40 \mathrm{mg} \text {, iodine, } 1.6 \mathrm{mg}\end{array}$} \\
\hline \multicolumn{2}{|c|}{${ }^{* * *}$ Ronozyme P5000 Phytase (DSM Nutritional Products, Netherlands) } \\
\hline${ }^{* * * *}$ From difference: dry matter - (cru & de fiber + ash) \\
\hline
\end{tabular}


Bogusławska-Tryk M, Piotrowska A, Głowińska B Szymeczko R, Burlikowska K,

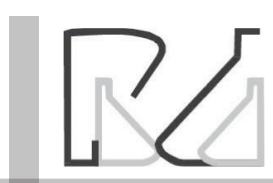

Table 2 - Fatty acid profile (\% of methyl esters) of the basal diet

\begin{tabular}{|c|c|}
\hline Fatty acid & Diet \\
\hline C14:0 Myristic & 0.23 \\
\hline C16:0 Palmitic & 32.71 \\
\hline C16:1 Palmitoleic & 0.29 \\
\hline C18:0 Stearic & 11.62 \\
\hline C18:1 Oleic & 26.74 \\
\hline C18:2n-6 Linoleic & 21.93 \\
\hline C18:3n-3 $\alpha$-Linolenic & 1.81 \\
\hline C20:0 Arachidic & 1.49 \\
\hline C20:1 Eicosenoic & 0.19 \\
\hline C20:2 Eicosadienoic & 0.12 \\
\hline C20:4n-6 Arachidonic & 0.36 \\
\hline C22:0 Behenic & 1.29 \\
\hline C24:0 Lignoceric & 0.54 \\
\hline Others & 0.68 \\
\hline SFA & 48.51 \\
\hline MUFA & 27.27 \\
\hline PUFA & 24.22 \\
\hline
\end{tabular}

SFA $=$ saturated fatty acids, MUFA $=$ monounsaturated fatty acids, PUFA $=$ polyunsaturated fatty acids

were as follows: neutral detergent fiber (NDF)- 81.1, 86.6, and $90.5 \mathrm{~g} \mathrm{~kg}^{-1}$, ADF- 29.0, 32.8, and $36.6 \mathrm{~g} \mathrm{~kg}^{-}$ 1, ADL - 4.9, 5.3 and $6.7 \mathrm{~g} \mathrm{~kg}^{-1}$ in diets with $0.25,0.5$ and $1.0 \%$ lignocellulose, respectively.

\section{Sampling analysis \\ procedures \\ and}

Dietary dry matter, crude protein, ether extract and fiber contents were determined according to standard methods (AOAC, 1990), and the concentrations of NDF, ADF and ADL were analyzed according to the Van Soest method (Van Soest, 1963). The density of ME $\mathrm{kg}^{-1}$ of diets was calculated from the analyzed chemical composition according to the DLG standard (1999).

The blood for analysis was collected from each bird at $42 \mathrm{~d}$ of age from the pterygoid canal vein. After coagulation, the blood samples were centrifuged at $3,000 \mathrm{~g}$ for $10 \mathrm{~min}$, and the serum was stored in a freezer at $-20^{\circ} \mathrm{C}$ until analyses. Blood serum triglyceride content (TG), total cholesterol (TCHOL), and high-
Lipid Metabolism Indices and Fatty Acids Profile in the Blood Serum of Broiler Chickens Fed a Diet with Lignocellulose

density lipoprotein (HDL) fraction were determined by the spectrophotometric method, using OLYMPUS AU 400 analyzer (Beckman Coulter Inc., US). The contents of low density (LDL) and very low density lipoprotein (VLDL) fractions in the serum were calculated based on Friedewald equation (Friedewald et al., 1972).

Lipids were extracted from blood serum by the chloroform-methanol (2:1), as described by Folch et al. (1957). The extracted fatty acids were esterified, and methyl esters were analyzed by CLARUS 600 GC/MS PerkinElmer equipped with an Elite-5MS (PerkinElmer, US) column $(30 \mathrm{~m}, 0.25 \mathrm{~mm}, 0.5 \mu \mathrm{m}$ film thickness). The analyses were carried out at the pre-programmed temperature of $140{ }^{\circ} \mathrm{C}(4 \mathrm{~min})-4^{\circ} \mathrm{C} / \mathrm{min}-270{ }^{\circ} \mathrm{C}$ ( $5 \mathrm{~min})$. The other parameters were: carrier gas He 6.0 at a flow of $1 \mathrm{~mL} / \mathrm{min}$, splitless, feeder $250^{\circ} \mathrm{C}$, transfer line $150^{\circ} \mathrm{C}$, ion source $200^{\circ} \mathrm{C}$, mass scan (m/z) 35-400. Fatty acid (FA) profile in the basal diet was determined according to the method described above. Based on the performed analyses, the contents of saturated (SFA), monounsaturated (MUFA), polyunsaturated (PUFA) and unsaturated fatty acids (UFA) were determined.

\section{Statistical analysis}

The results are expressed as the mean and standard error of the mean (SEM). The data were statistically analyzed by one-way ANOVA using the Statistica 8.0 PL software. The post-hoc Duncan test was applied and the significance level was set at $p<0.05$.

\section{RESULTS}

Significant $(p<0.05)$ dose-dependent differences were found in the concentration of lipid metabolites in the blood serum of 6-week-old birds (Table 3). Lignocellulose at the dose of $1.0 \%$ significantly reduced $(p<0.05)$ the concentration of $\mathrm{TG}$, and at 0.5 and $1.0 \%$ significantly lowered $(p<0.05)$ LDL cholesterol in the supplemented birds compared with the non-supplemented group. Moreover, inclusion

Table 3 - Lipid metabolism indices ( $\mathrm{mmol} / \mathrm{l})$ in the blood serum of broiler chickens at 42 days of age fed diets without and with lignocellulose at a dose of $0.25,0.5$ and $1 \%$ (mean \pm SEM).

\begin{tabular}{lccccc}
\hline \multirow{2}{*}{ Parameter } & \multicolumn{4}{c}{ Lignocellulose in the diet (\%) } \\
\cline { 2 - 5 } & 0.0 & 0.25 & 0.5 & 1.0 & $1.13^{\mathrm{b}} \pm 0.10$ \\
\hline Triglyceride & $1.26^{\mathrm{a}} \pm 0.12$ & $1.18^{\mathrm{ab}} \pm 0.08$ & $1.20^{\mathrm{ab}} \pm 0.11$ & 0.039 \\
Total cholesterol & $3.56 \pm 0.10$ & $3.53 \pm 0.11$ & $3.31 \pm 0.09$ & $3.32 \pm 0.10$ & 0.159 \\
HDL & $1.99 \pm 0.06$ & $2.13 \pm 0.03$ & $2.07 \pm 0.07$ & $2.17 \pm 0.06$ & 0.356 \\
LDL & $1.32^{\mathrm{a}} \pm 0.04$ & $1.16^{\mathrm{ab}} \pm 0.06$ & $1.00^{\mathrm{b}} \pm 0.05$ & $0.92^{\mathrm{b}} \pm 0.05$ & 0.031 \\
VLDL & $0.25 \pm 0.02$ & $0.24 \pm 0.02$ & $0.24 \pm 0.02$ & $0.23 \pm 0.03$ \\
\hline
\end{tabular}

SEM=standard error of the mean; $a, b-$ means in a row with different letters differ significantly $(p<0.05)$; HDL=high density lipoprotein, LDL=low density lipoprotein, VLDL=very low density lipoprotein 
Bogusławska-Tryk M, Piotrowska A, Szymeczko R, Burlikowska K, Głowińska B

\section{Lipid Metabolism Indices and Fatty Acids Profile in the Blood Serum of Broiler Chickens Fed a Diet with Lignocellulose}

of fiber in broiler diets from 21 to $42 \mathrm{~d}$ of rearing tended to decrease total cholesterol and enhance HDL cholesterol in the serum; however, this effect was not statistically significant.

Fatty acid profile in the blood serum of chickens (Table 4) takes into account only those FA, which percentage share in total fatty acid pool exceeded $0.05 \%$. The sum of saturated and monounsaturated fatty acids and their individual concentrations were not significantly influenced by the different levels of lignocellulose in the diet. In the blood of all broilers, the main saturated FA was palmitic acid (C16:0), which accounted for $63.3 \%$ to $64.5 \%$ of SFA, whereas oleic acid (C18:1n-9 cis) was predominant among monounsaturated FA, and its share in total MUFA was 86.7-88.2\%. Among polyunsaturated FA, linoleic acid (LA) (C18:2n-6 cis) was definitely predominated and accounted for more than $85 \%$ of the PUFA in the blood. Despite the lack of differences in total polyunsaturated FA concentrations among the treatment groups, insoluble fiber influenced the serum PUFA profile. Lignocellulose at $1.0 \%$ significantly reduced $(p<0.05)$ $\alpha$-linolenic acid (ALA) levels (C18:3n-3), and increased $(p<0.05)$ docosahexaenoic acid (DHA) (C22:6n-3 cis) and dihomogammalinolenic acid (DHgL) (C20:3n-6 cis) levels. Also, higher $(p<0.05)$ serum concentrations of arachidonic acid (AA) (C20:4n-6) and DHA were observed in broilers fed the diet with $0.5 \%$ lignocellulose, compared to the non-supplemented group. However, these significant differences in the profile of PUFA were not reflected in the $n-3: n-6$ ratios, or in SFA:UFA and MUFA:PUFA ratios in the blood serum of chickens fed the diets supplemented with lignocellulose (Table 4).

\section{DISCUSSION}

Lipid metabolites in the chicken blood, including the levels of triglycerides, total cholesterol, lipoprotein fractions, as well as the fatty acids profile, are sensitive indicators of fat metabolism intensity in the organism. Also, it is widely accepted that the values of these parameters in broiler chickens depend on several factors, such as age, sex, genetic type, and environmental and feeding conditions (Meluzzi et al. 1992; Krasnodębska-Depta \& Koncicki, 2000). It is documented that moderate amounts of cellulose or oat hulls fiber positively affect the total tract ether extract retention (Jiménez-Moreno et al., 2010), liver lipid metabolism and, consequently, the levels of serum lipid metabolites in broilers (Akiba \& Matsumoto, 1982; Safaa et al., 2014).

Table 4 - Fatty acids profile (\%) in the blood serum of broiler chickens at 42 days of age fed diets without and with lignocellulose at a dose of $0.25,0.5$ and $1 \%$ (mean \pm SEM)

\begin{tabular}{|c|c|c|c|c|c|}
\hline \multirow{2}{*}{ Fatty acid } & \multicolumn{4}{|c|}{ Lignocellulose in the diet (\%) } & \multirow{2}{*}{$P$ value } \\
\hline & 0.0 & 0.25 & 0.5 & 1.0 & \\
\hline C 14:0 & $0.13 \pm 0.01$ & $0.13 \pm 0.01$ & $0.13 \pm 0.01$ & $0.14 \pm 0.01$ & 0.511 \\
\hline C16:0 & $26.74 \pm 0.58$ & $26.73 \pm 0.49$ & $26.15 \pm 0.68$ & $27.15 \pm 0.62$ & 0.702 \\
\hline C 16:1 & $1.18 \pm 0.13$ & $1.25 \pm 0.11$ & $1.07 \pm 0.12$ & $1.04 \pm 0.12$ & 0.052 \\
\hline C18:0 & $14.79 \pm 0.44$ & $15.28 \pm 0.20$ & $15.05 \pm 0.44$ & $14.82 \pm 0.51$ & 0.875 \\
\hline C $18: 1 n-9$ cis & $15.51 \pm 0.74$ & $15.71 \pm 1.02$ & $15.24 \pm 0.77$ & $16.10 \pm 1.03$ & 0.421 \\
\hline C18:1n-9 trans & $1.10 \pm 0.06$ & $1.12 \pm 0.08$ & $1.10 \pm 0.05$ & $1.06 \pm 0.05$ & 0.672 \\
\hline C $18: 2 n-6$ cis & $35.02 \pm 0.72$ & $34.92 \pm 1.06$ & $34.89 \pm 0.68$ & $33.69 \pm 0.57$ & 0.125 \\
\hline C18:3n-3 & $1.36^{\mathrm{a}} \pm 0.03$ & $1.18^{\mathrm{ab}} \pm 0.07$ & $1.19^{\mathrm{ab}} \pm 0.04$ & $1.04^{b} \pm 0.03$ & $<0.001$ \\
\hline$C 20: 3 n-3$ & $0.50 \pm 0.02$ & $0.48 \pm 0.02$ & $0.53 \pm 0.03$ & $0.54 \pm 0.06$ & 0.725 \\
\hline $\mathrm{C} 20: 3 \mathrm{n}-6$ cis & $0.13^{b} \pm 0.00$ & $0.15^{b} \pm 0.02$ & $0.14^{b} \pm 0.01$ & $0.19^{\mathrm{a}} \pm 0.01$ & 0.001 \\
\hline$c 20: 4 n-6$ & $2.64^{b} \pm 0.48$ & $2.11^{b} \pm 0.24$ & $3.42^{\mathrm{a}} \pm 0.43$ & $3.16^{\mathrm{ab}} \pm 0.63$ & 0.026 \\
\hline C20:5n-3 cis & $0.33 \pm 0.03$ & $0.37 \pm 0.07$ & $0.36 \pm 0.04$ & $0.35 \pm 0.04$ & 0.421 \\
\hline$C 22: 1 n-9$ & $0.07 \pm 0.01$ & $0.04 \pm 0.00$ & $0.06 \pm 0.01$ & $0.06 \pm 0.01$ & 0.274 \\
\hline C22: $6 n-3$ cis & $0.21^{b} \pm 0.03$ & $0.26^{\mathrm{ab}} \pm 0.04$ & $0.31^{a} \pm 0.03$ & $0.34^{a} \pm 0.07$ & 0.008 \\
\hline Others & $0.30 \pm 0.02$ & $0.28 \pm 0.01$ & $0.36 \pm 0.06$ & $0.33 \pm 0.02$ & 0.278 \\
\hline SFA & $41.66 \pm 0.48$ & $42.14 \pm 0.38$ & $41.33 \pm 0.30$ & $42.11 \pm 0.31$ & 0.348 \\
\hline MUFA & $17.86 \pm 0.84$ & $18.12 \pm 1.69$ & $17.47 \pm 0.88$ & $18.26 \pm 1.13$ & 0.423 \\
\hline PUFA & $40.19 \pm 1.07$ & $39.47 \pm 1.80$ & $40.84 \pm 0.82$ & $39.31 \pm 1.16$ & 0.126 \\
\hline SFA:UFA & $0.72 \pm 0.01$ & $0.73 \pm 0.01$ & $0.71 \pm 0.01$ & $0.73 \pm 0.01$ & 0.298 \\
\hline MUFA:PUFA & $0.44 \pm 0.02$ & $0.46 \pm 0.04$ & $0.43 \pm 0.03$ & $0.46 \pm 0.04$ & 0.369 \\
\hline$n-3: n-6$ & $0.06 \pm 0.00$ & $0.06 \pm 0.00$ & $0.06 \pm 0.00$ & $0.06 \pm 0.00$ & 0.741 \\
\hline
\end{tabular}

SEM=standard error of the mean; $a, b-$ means in a row with different letters differ significantly $(p<0.05)$; SFA=saturated fatty acids, UFA=unsaturated fatty acids (MUFA+PUFA), MUFA=monounsaturated fatty acids, PUFA=polyunsaturated fatty acids 
Bogusławska-Tryk M, Piotrowska A, Szymeczko R, Burlikowska K, Głowińska B

In the present study, the serum content of triglyceride and total cholesterol in all experimental birds were within the physiological ranges determined for 6-weekold chicks (Krasnodębska-Depta \& Koncicki, 2000; Silva et al., 2007; Mazurkiewicz, 2011). However, lignocellulose at $0.5-1.0 \%$ significantly lowered serum TG level, revealing a desirable effect on the lipoprotein profile of chickens. The observed TG concentration reduction and slight TCHOL content decrease resulted in a slight HDL increase and significant LDL decrease in the broilers serum.

The results of our study confirm the hypothesis of non-fermentable fiber incorporated into broiler diets has hypolipidemic effects. Safaa et al. (2014) observed that increasing inclusion levels of oat hulls in broiler diets $(2.5,5.0$ and $7.5 \%)$ caused a linear reduction in liver lipid components, namely triglycerides and total cholesterol, in 21-d-old broilers. The authors detected a simultaneously decrease in total cholesterol content and a linear increase in HDL level in the serum with increasing levels of insoluble fiber in the diets. According to those authors, the detected hypolipidemic effect of dietary fiber results mainly from its impact on liver lipid metabolism. The same trend was observed by Sarikhan et al. (2009) in broiler chickens fed diets supplemented with low levels (up to $0.75 \%$ ) of insoluble raw fiber concentrate (IRFC) during the entire rearing period. Those researchers found reduced levels of serum triglycerides, total cholesterol, and LDL cholesterol and increased levels of HDL cholesterol in response to increasing dietary IRFC levels when broilers were 42 days old. According to Sarikhan et al. (2009), the reduction of serum lipid metabolite levels promoted by dietary effect of insoluble fiber may be explained by the ability of fiber to bind the bile lipids in the gut. The hypolipidemic effect of lignocellulose observed in our study may be also attributed to capacity of lignin to bind bile acids in the intestinal lumen (Jung \& Fahey, 1983), which may increase the fecal excretion of cholesterol and lower serum lipids.

The changes in serum lipid profile may also partially the result of the prebiotic effect of lignocellulose on the broiler intestinal microflora population. Our previous studies demonstrated that the inclusion of low amounts (0.25-1.0\%) of lignocellulose to a broiler diet reduced the number of potential pathogens and promoted the growth of Lactobacillus spp. and Bifidobacterium spp. in the ileal and cecal digesta (Bogusławska-Tryk et al., 2015). Gilliland et al. (1985) demonstrated that certain strains of Lactobacillus acidophilus, under specific invitro conditions, are able to assimilate cholesterol from
Lipid Metabolism Indices and Fatty Acids Profile in the Blood Serum of Broiler Chickens Fed a Diet with Lignocellulose

the medium. Panda et al. (2006) reported that serum concentration of TG, TCHOL, LDL and VLDL cholesterol fractions were significantly reduced when broilers were fed diets supplemented with a probiotic containing Lactobacillus sporogenes, which may be associated with utilization of cholesterol by the probiotic bacteria for their own metabolism.

It is obvious that the blood level and profile of fatty acids are indicators of their dietary intake as well as of their absorption and metabolism in animal tissues. There is no information in current literature on the influence of insoluble dietary fiber (i.e., cellulose and lignin) on fatty acid absorption and profile in the chicken serum, and therefore, it is difficult to compare the results of the present study. Hence, our research should be considered as a precursory study in this area.

Linoleic acid (C18:2n-6 cis) and $\alpha$-linolenic acid (C18:3n-3) are essential fatty acids for vertebrates as these do not have endogenous enzymatic systems for the de-novo synthesis of those fatty acids. When supplied in the diet, they can be bioconverted in animal tissues by elongation and desaturation into physiologically essential long-chain PUFA of the n-3 and n-6 families (Pfeuffer, 2001; Poureslami at al., 2010). The results of the present study showed that lignocellulose significantly influenced the profile of n-3 and n-6 polyunsaturated fatty acids in the blood serum of broilers. We observed a significant decrease in $\alpha$-linolenic acid (ALA) and increase in concentration of its derivative (DHA) when lignocellulose was fed. We also noted a substantial increase in serum dihomogamma-linolenic and arachidonic acids concentrations, with a simultaneous tendency of reduction of $L A$ (parent form of PUFA from n-3 family) levels with increasing level of lignocellulose in the diet. The observed changes in the serum fatty acid profile may be attributed to the action of insoluble fibers on lipid metabolism in the body. Some studies showed that enrichment of broiler diet with pure cellulose or oat hulls reduced abdominal fat content and liver weight, as well as hepatic lipid accumulation (Akiba \& Matsumoto, 1982; Mohiti-Asli et al., 2012; Safaa et al., 2014). Akiba \& Matsumoto (1978) observed that feeding cellulose resulted in a reduction of hepatic de-novo fatty acids synthesis and triglyceride concentration, as well as in changes in the TG profile of the lipid content of the liver in force-fed broilers. Those authors noted an increase in oleic acid content and a decrease in palmitic and stearic acid concentration, as well as a slight increase in unsaturated to saturated FA ratio of liver triglycerides. It may be assumed that, under the influence of dietary 
Bogusławska-Tryk M, Piotrowska A, Szymeczko R, Burlikowska K, Głowińska B

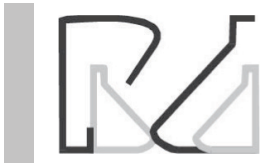

fiber, changes in hepatic lipid metabolism are reflected in the values of biochemical parameters, including blood fatty acid profile.

In conclusion, this study demonstrated that the incorporation of limited amounts of lignocellulose into the diet lowered triglyceride concentration and had a desirable effect on serum lipoprotein profile of broilers. Lignocellulose significantly influenced the n-3 and n-6 PUFA profile. These results suggest that lignocellulose can affect the lipid metabolism of broilers. Since there are no previous reports on the effects of lignocellulose on lipid metabolism indices of chickens, the obtained results need be confirmed in further studies investigating its impact on fat deposition and tissue fatty acid profile in broilers.

\section{REFERENCES}

Akiba Y, Matsumoto T.Effects of force-feeding and dietary cellulose on liver lipid accumulation and lipid composition of liver and plasma in growing chicks. Journal of Nutrition 1978;108:739-748.

Akiba Y, Matsumoto T. Effects of dietary fibers on lipid metabolism in liver and adipose tissue in chicks. Journal of Nutrition 1982;112:1577-1585.

AOAC. Official method of analysis. 15th ed Arlington: Association of Official Analytical Chemists; 1990.

Bogusławska-Tryk M, Szymeczko R, Piotrowska A, Burlikowska K, Śliżewska $K$. Ileal and cecal microbial population and short-chain fatty acid profile in broiler chickens fed diet supplemented with lignocellulose. Pakistan Veterinary Journal 2015;35:212-216.

DLG. Gessellschaft für Ernährungsphysiologie, Empfehlungen zur Energie - und Nährstoffversorgung der Legehennen und Masthühner (Broiler). Frankfurt: DLG-Verlag; 1999.

Farran MT, Pietsch M, Chabrillat T. Effect of lignocellulose on the litter quality and the ready to cook carcass yield of male broilers. Actes des 10 èmes Journées de Recherche Avicole et Palmipèdes à Foie Gras; 2013 Mars 26-28 ; La Rochelle. France. p.917-921.

Folch $\mathrm{H}$, Less M, Staney HA. A simple method for isolation and purification of total lipids from animal tissues. Journal of Biological Chemistry 1957:226:497-499.

Friedewald WT, Levy RI, Fredrickson DS. Estimation of the concentration of low-density lipoprotein cholesterol in plasma, without use of the preparative ultracentrifuge. Clinical Chemistry 1972;18:499-502.

Gilliland SE, Nelson CR, Maxwell C. Assimilation of cholesterol by Lactobacillus acidophilus. Applied and Environmental Microbiology 1985;49:377-381.

Harmsen PFH, Huijgen WJJ, Bermúdez López LM, Bakker RRC. Literature review of physical and chemical pretreatment processes for lignocellulosic biomass. Wageningen: Wageningen University \& Research Centre; 2010. Available from: ftp://ftp.ecn.nl/pub/www/ library/report/2010/e10013.pdf.

Jiménez-Moreno E, González-Alvarado JM, González-Sánchez D, Lázaro R, Mateos GG. Effects of type and particle size of dietary fiber on growth performance and digestive traits of broilers from 1 to 21 days of age. Poultry Science 2010;89:2197-2212.

\section{Lipid Metabolism Indices and Fatty Acids Profile in the Blood Serum of Broiler Chickens Fed a Diet with Lignocellulose}

Jung HG, Fahey Jr GC. Nutritional implications of phenolic monomers and lignin: a review. Journal of Animal Science 1983;57:206-219.

Klapáčová K, Faixová Z, Grešáková L, Faix Š, Miklósová L, Leng L. Effects of feeding wheat naturally contaminated with Fusarium mycotoxins on blood biochemistry and the effectiveness of dietary lignin treatment to alleviate mycotoxin adverse effects in broiler chickens. Acta Veterinaria Beograd 2011;61:227-237.

Krasnodębska-Depta A, Koncicki A. Physiological values of selected serum biochemical indices in broiler chickens. Medycyna Weterynaryjna 2000;56:456-460.

Mateos GG, Jiménez-Moreno E, Serrano MP, Lázaro RP. Poultry response to high levels of dietary fiber sources varying in physical and chemical characteristics. Journal of Applied Poultry Research 2012;21:156-174.

Mazurkiewicz M. Poultry disease. 2nd ed. Wrocław: University of Environmental and Life Sciences ; 2011.

Meluzzi A, Primiceri G, Giordani R, Fabris G. Determination of blood constituents reference values in broilers. Poultry Science 1992;71:337345 .

Mohiti-Asli M, Shivazad M, Zaghari M, Aminzadeh S, Rezaian M, Mateos GG. Dietary fibers and crude protein content alleviate hepatic fat deposition and obesity in broiler breeder hens. Poultry Science 2012;91:3107-3114.

Montagne L, Pluske JR, Hampson DJ. A review of interactions between dietary fibre and the intestinal mucosa, and their consequences on digestive health in young non-ruminant animals. Animal Feed Science and Technology 2003;108:95-117.

Panda AK, Rama Rao SV, Raju MVLN, Sharma SR. Dietary supplementation of Lactobacillus sporogenes on performance and serum biochemicolipid profile of broiler chickens. Journal of Poultry Science 2006;43:235240 .

Pfeuffer M. Physiologic effects of individual fatty acids in animal and human body, with particular attention to coronary heart disease risk modulation. Archiv Tierzucht 2001;44:89-98.

Poureslami R, Raes K, Turchini GM, Huyghebaert G, de Smet S. Effect of diet, sex and age on fatty acid metabolism in broiler chickens: $n-3$ and n-6 PUFA. British Journal of Nutrition 2010;104:189-197.

Safaa HM, Jiménez-Moreno E, Frikha M, Mateos GG. Plasma lipid metabolites and liver lipid components in broilers at 21 days of age in response to dietary different fiber sources. Egyptian Journal of Animal Production 2014;51:115-127.

Sarikhan M, Shahryar HA, Nazer-Adl K, Gholizadeh B, Beheshti B. Effects of insoluble fiber on serum biochemical characteristics in broiler. International Journal of Agriculture \& Biology 2009;11:73-76.

Sarikhan M, Shahryar HA, Gholizadeh B, Hosseinzadeh MH, Beheshti B, Mahmoodnejad A. Effects of insoluble fiber on growth performance, carcass traits and ileum morphological parameters on broiler chick males. International Journal of Agriculture \& Biology 2010;12:531-536.

Silva PRL, Freitas Neto OC, Laurentiz AC, Junqueira OM, Fagliari JJ. Blood serum components and serum protein test of Hybro-PG broilers of different ages. Brazilian Journal of Poultry Science 2007;9:229-232.

Van Soest PJ. Use of detergents in the analysis of fibrous feeds. II. A Rapid method for the determination of fiber and lignin. Journal of the Association of Official Agricultural Chemists 1963;46:829-835. 